\title{
Covid-19 Sürecinde Online Eğitimin Akademisyenlerin Örgütsel Stresine Etkisi: Harran Üniversitesi Örneği
}

\author{
DOI: 10.26466/opus.939850
}

\author{
Abdullah Çelik* - Fatmanur Aksöz ${ }^{* *}$ \\ * Prof. Dr, Harran Üniversitesi, İ.̇̇.B.F., Kamu Yönetimi Bölümü, Şanlıurfa/Türkiye \\ E-Posta: $\quad$ acelik@harran.edu.tr \\ ORCID: $\quad$ 0000-0002-9413-7918 \\ ** Arş. Gör., Harran Üniversitesi, İ.İB.F., Kamu Yönetimi Bölümü, Şanlıurfa/Türkiye \\ E-Posta: $\quad$ f.aksoz@harran.edu.tr \\ ORCID: $\underline{\text { 0000-0003-4765-0986 }}$
}

Öz

COVID-19 pandemisi tüm dünyayı etkisi altına almış ve hayatımızın her alanında ciddi değiş̧ikliklere yol açmıştır. Bu bağlamda uzaktan eğitim sistemine yapılan hızlı bir geçişle birlikte pandemiden etkilenen önemli bir kesim de akademisyenler olmuştur. COVID-19 pandemisine dair literatürde akademik çalışmalar bulunmakla birlikte bu süreçte uzaktan eğitimin akademisyenler üzerinde

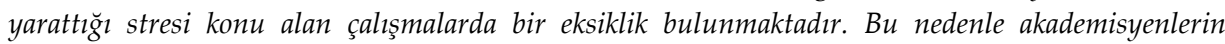
uzaktan eğitime dair görüşlerinin alınarak sürecin akademisyenlerin örgütsel streslerine olan etkisinin incelenmesi önem arz etmektedir. Bu çalısmada, COVID-19 pandemisi sürecinde bir kamu hizmeti olarak uzaktan eğitimin, akademisyenlerin örgütsel stresi üzerindeki etkisinin tespit edilmesi amaçlanmıştır. Çalışma Harran Üniversitesi'nde 2020-2021 eğitim-öğretim yılı bahar döneminde görev yapmakta olan 278 akademisyen üzerinde gerçekleştirilmiştir. Katıllmcilara online olarak anket uygulanmıştır. Veri toplama aracı olarak "web tabanlı öğretim tutum ölçeği" ve "örgütsel stres ölçeği" kullanılmıştır. Çalışma sonuçları SPSS programında analiz edilmiştir. Elde edilen verilerin analizleri sonucunda, web tabanl öğretimin etkililiğinin örgütsel stres üzerinde anlamlı bir etkisinin bulunmadığı ve bu iki değişken arasında anlamlı bir ilişkinin olmadığı sonucuna ulaşılmıştır. Web tabanlı öğretime karşı direnmenin ise örgütsel stres üzerinde etkisinin olduğu ve aralarında anlaml bir ilişkinin bulunduğu tespit edilmiştir.

Anahtar Kelimeler: Covid-19, Uzaktan Eğitim, Akademisyen, Örgütsel Stres. 


\title{
The Effect of Online Education on Organizational Stress of Academicians in Covid-19 Process: The Case of Harran University
}

$*$

\begin{abstract}
The COVID-19 pandemic has affected the whole world and has caused serious changes in every aspect of our lives. In this context, with the rapid transition to the distance education system, a significant group of people affected by the pandemic has been academicians. Although there are academic studies in the literature on the COVID-19 pandemic, there is a lack of studies on the stress of distance education on academics in this process. For this reason, it is important to examine the effects of the process on the organizational stress of academicians by taking the views of academicians on distance education. In this study, it was aimed to determine the effect of distance education as a public service on the organizational stress of academicians during the COVID-19 pandemic process. The study was carried out on 278 academicians working at Harran University in the spring semester of the 20202021 academic year. An online questionnaire was applied to the participants. "Web-based teaching attitude scale" and "organizational stress scale" were used as data collection tools. The results of the study were analyzed in the SPSS program. As a result of the analysis of the data obtained, it was concluded that the effectiveness of web-based teaching did not have a significant effect on organizational stress and there was no significant relationship between these two variables. On the other hand, it has been determined that resistance to web-based teaching has an effect on organizational stress and there is a significant relationship between them.
\end{abstract}

Key Words: Covid-19, Distance Education, Academician, Organizational Stress. 


\section{Giriş}

Tarihsel sürece bakıldığında dünya üzerinde çeşitli salgınların insan hayatında etkili olduğu görülmektedir. Günümüzde ise dünya gündemini bir anda sarsan COVID-19 pandemisi ile mücadele hala devam etmektedir. COVID-19 pandemisinin hayatımıza girmesi ile birlikte tüm dünyada günlük hayatın ritmi tamamen değişmiştir. Pandeminin yüksek bulaşıcı özelliği nedeniyle yayılımını ve etkisini azaltmak için çeşitli önlemler alınmıştır. Bu önlemler ekonomi, siyaset, sosyal hayat, psikoloji ve eğitim üzerinde değişiklikler meydana getirmiş ve yeni normal olarak adlandırılan bir düzene geçiş gerçekleştirilmiştir.

Söz konusu olan bu yeni düzende, eğitim sistemi de zaruri olarak ani bir değişim ile uzaktan eğitim sistemine dönüşmüştür. Bu kapsamda tüm eğitim kademelerinde olduğu gibi yükseköğretim sisteminde de uzaktan eğitim uygulamasına geçiş yapılmıştır. $\mathrm{Bu}$ durum akademisyenlerin çalışma koşullarını ve yaşam tarzlarını etkilemiştir. Zira hayatımızda gündelik rutinlerimizi bozan belirsizliğe neden olan faktörlerin stres yarattığ ${ }_{1}$ bilinmektedir. Bu noktada COVID-19 pandemi sürecinde ani bir şekilde uzaktan eğitime geçilmesinin, akademisyenlerin örgütsel stresine olan etkisinin araştırılması gerekli görülmüştür.

Bu çalışmada öncelikli olarak COVID-19 süreci, uzaktan eğitim ve örgütsel stres gibi konular kavramsal olarak ele alınmaktadır. Daha sonra çalışmanın uygulama kısmında ise, COVID-19 sürecinde görev yapan akademisyenlerin örgütsel stres düzeylerinin uzaktan eğitimden nasıl etkilendiği ortaya konmaya çalışılmaktadır.

Çok yönlü bir sorun olan COVID-19 pandemisine dair literatürde pek çok çalışma mevcuttur. Ancak bu süreçte uzaktan eğitimin akademisyenler üzerinde meydana getirdiği stresi konu alan çalışmalarda bir eksiklik bulunmaktadır. Bu durum çalışmayı benzerlerinden ayırarak özgün kılmaktadır. Bu nedenle yapılan çalışmanın literatürdeki, azda olsa, bir eksikliği gidererek devam eden süreçteki çalışmalara katkı sunabileceği düşünülmekte ve çalışmanın yapılması önemli görülmektedir. 


\section{Covid-19 Sürecine Genel Bir Bakış}

Tüm dünyayı etkisi altına alan COVID-19 pandemisi, ilk kez Çin'in Wuhan şehrinde, 2019 yılının aralık ayında, ateş, öksürük, nefes darlığ 1 gibi solunum yolu belirtileri görülen hastalarda yapılan araştırmalar neticesinde tanımlanan bir virüstür (Aydın ve Doğan, 2020, s.94). 31 Aralık 2019 tarihinde, Dünya Sağlık Örgütü Çin Ülke Ofisi, Çin'in Wuhan şehrinde, nedeni $\mathrm{o}$ an için bilinmeyen zatürre vakaları bildirmiştir. Bildirim sonucunda 5 Ocak 2020 tarihinde daha önce insanlarda görülmemiş yeni bir koronavirüs tespit edilmiştir. Hastalık başlangıçta 2019- nCoV şeklinde ifade edilirken sonrasında COVID-19 olarak adlandırılmış ve yüksek bulaşma özelliği gösteren virüs, kısa sürede başta Avrupa olmak üzere bütün dünyayı etkisi altına almıştır (Budak ve Korkmaz, 2020, s.66). 11 Mart 2020 tarihinde, COVID-19, Dünya Sağlik Örgütü tarafından küresel bir pandemi olarak ilan edilmiştir. Türkiye'deki ilk COVID-19 vakası, 11 Mart 2020 tarihinde, Türkiye Cumhuriyeti Sağlık Bakanlığı tarafından açılanmıştır. Türkiye'de virüse bağlı ilk ölüm, 15 Mart 2020 tarihinde gerçekleşmiştir. Sağlık Bakanı, 1 Nisan 2020 tarihinde bir açıklama yaparak koronavirüs vakalarının tüm Türkiye'ye yayıldığını ifade etmiştir (Güreşçi, 2020, s.57).

Türkiye, neredeyse kendisinden altı bin kilometre uzaklıkta başlayan bu pandemiyi başından itibaren ciddiyetle takip etmiş ve Türkiye'de henüz vaka görülmeden gerekli önlemler alınmaya başlanmıştır. İlk vakanın açıklanmasıyla birlikte öncelikle krizden kaçma daha sonra krizi çözme yaklaşımı benimsenmiştir (Güngör, 2020, s.844-845). Nitekim COVID-19 pandemisi tüm dünyada sağlık başta olmak üzere ekonomik, politik, psikolojik, sosyo-kültürel, sosyal yaşam ve eğitim uygulamaları üzerinde derin etkiler yaratmış ve hayatın akışı küresel düzeyde değişmiştir. Bu düşünceler ekseninde COVID-19 sonrası dünyada yaşananların, yeni normal ve yeni paradigma oluşturduğunu, bu durumun ise yeni bir dünya düzenini doğuracağını söylemek mümkündür (Bozkurt, 2020, s.113; Can, 2020, s.12).

Pandeminin etkisini azaltmak ve yüksek bulaşıcı özelliğinden dolayı yayılımını yavaşlatmak için esnek çalışma, dönüşümlü çalışma, evden çalışma gibi uygulamalara geçiş yapılmıştır. Dahası tüm dünyada kısmi 
veya tam zamanlı sokağa çıkma yasakları, seyahat kısıtları, sınırların uçuşlara kapatılması, sosyal mesafenin korunması, bireylerin kendilerini izole etmeleri ve karantina süreçleri gibi ciddi önlemler alınmıştır. Bu önlemler doğrultusunda insanlar arasında temasın olabileceği yerler kapatılmış, ciddi oranda insan etkileşimine sahip olan okullar ve üniversiteler de bu kapsama dâhil edilmiştir. Kısıtlamalar ve tedbirler nedeniyle ani bir şekilde tüm dünya ülkeleri normal hayatı değiştirmek durumunda kalmıştır. Zira normal olmayan bir sürece girilmiştir (Bozkurt, 2020, s.114; Aydın ve Doğan, 2020, s.95).

COVID-19 pandemisinin yayılmasını kontrol altına almaya yönelik tedbirler, küresel düzeyde eğitim sistemlerini de etkilemiş ve eğitim kurumlarının kapatılmasına karar verilmiştir. Bu kapsamda COVID-19 pandemisi yükseköğretim sistemini de ciddi bir şekilde etkilemiştir.

Türkiye'de yükseköğretim sistemine 12 Mart 2020 tarihinde ara verilmiş, 23 Mart 2020 tarihinden itibaren ise öğretim sürecinin tamamen uzaktan eğitime dönüştürülmesi kararlaştırılmıştır (YÖK, 2020f). Ayrıca, Yükseköğretim Kurulunca alınan kararla, koronavirüs salgını nedeniyle ön lisans, lisans ve lisansüstü düzeyde öğrenim gören öğrencilerin talep etmeleri halinde 2019-2020 eğitim-öğretim yılı bahar döneminde kayıtlarını dondurabilmesine; tez savunma ve yeterlik sinavlarının ise denetlenebilir olma ve "kayıt altına alınmak şartıyla" video konferans gibi dijital imkânlar ile yapılabilmesine olanak sağlanmıştır (YÖK, 2020g). Bu açıklamalarla beraber, bütün öğretim kademelerinde yüz yüze eğitime ara verilmiş, uzaktan eğitim sistemine geçiş yapılmış, öğrencilerin başarısını ölçme ve değerlendirme işlemleri de web tabanlı olarak gerçekleştirilmiş, merkezi sınavlar ise ertelenmiştir. Böylelikle, örgün eğitimde mevcut olan sistemin ivedilikle web tabanlı uzaktan eğitim sistemine dönüştürülmesi zaruri olmuştur (Keskin ve Özer Kaya, 2020, s.60). Nitekim COVID-19 pandemisi nedeni ile uzaktan eğitim, tüm öğretim kademeleri için temel öğrenme kaynağı haline gelmiştir. Bu durum, ülkeleri, eğitim sistemlerini ayakta tutmak ve uzaktan eğitim sisteminin kalitesini arttırmak için yenilikler yapmaya ve uzaktan eğitime erişimi kesintisiz bir hale getirmeye zorlamıştır (Can, 2020, s.13). 


\section{Web Tabanlı Uzaktan Eğitim}

Uzaktan eğitim zamandan ve mekândan bağımsız bir şekilde sunulabilen, farklı teknolojileri öğrenim sürecine dâhil edebilen, materyalleri elektronik ortama uygun bir şekilde yapılandırabilen, güncellenebilen ve 7 gün 24 saat kullanılabilen çağdaş ve etkin bir öğrenme biçimidir (Yamamoto ve Altun, 2020, s.29). En kısa haliyle, uzaktan eğitim terimi öğrenci ile eğitmenin fiziksel olarak ayrı ortamlarda bulunmaları ile gerçekleşen eğitimi ifade etmektedir (Akdemir, 2011, s.69).

Web tabanlı uzaktan eğitim sistemi yalnızca ders içeriğinin internet üzerinden erişilebilir olduğu bir sistem değildir. Aynı zamanda öğrencilerin tanımlandığı, takip edildiği, ders içeriklerinin yönetildiği, ödev ve sınav sistemlerinin uygulandığı, öğrencinin başarı durumlarının değerlendirildiği bir sistemdir (Düzakın ve Yalçınkaya, 2008, s.231).

Uzaktan eğitim, tıpkı yüz yüze eğitimde olduğu gibi öğrencilerin belli bilgiler, beceriler ve tutumlar ile donatılmasinı hedeflemelidir. $\mathrm{Bu}$ nedenle uzaktan eğitimin öğrencilerin yaşlarına, psikolojilerine ve niteliklerine göre motivasyonlarını arttıracak bir şekilde tasarlanması gerekmektedir. E-ölçme ve değerlendirme araçlarının geliştirilmesi, sanal ortamdaki yenilikçi teknikler ile ders programlarının bütünleştirilmesi ve tartışma platformlarının oluşturulması ile kaliteli ve yenilikçi bir uzaktan eğitim sistemi sağlanabilir (Atasoy vd, 2020, s.100).

Uzaktan eğitim ilk kez 1728 yılında posta yöntemiyle uygulanmıştır. Günümüzde uzaktan eğitim sistemi her geçen gün gelişmekte ve birbirinden uzakta bulunan öğrenciler ve eğitmenler internet üzerinden yazıll, sözlü ve görüntülü iletişim kurabilmektedir (İ̧sman, 2011, s.3).

Türkiye'de uzaktan eğitim çalışmaları ilk kez 1924 yılında ünlü eğitimci John Dewey tarafından yazılan "Report and Recommendation upon Turkish Education" (Türk Eğitimi Üzerine Öneriler ve Rapor) adlı rapor ile gündeme gelmiştir. Esasında Türkiye'de 1923-1955 arası dönemde uzaktan eğitim kavramsal olarak tartışılmıştır. Türk eğitim sisteminde uzaktan eğitim ilk kez 1950 yılında mektup ile öğretimle gerçekleşmiştir.

1980 sonrasında Anadolu Üniversitesi Açık Öğretim Fakültesi'nin kurulmasıyla uzaktan eğitim çalışmaları yükseköğretime taşınmıştır. 
Anadolu Üniversitesi'nde 2547 sayılı Yükseköğretim Kanunu ile Açık Öğretim Fakültesi kurulmuş, ilk öğrencilerini ise 1982-1983 eğitimöğretim yılında almıştır. Böylelikle ülkemizdeki uzaktan eğitim sistemi yükseköğretim düzeyinde yerini almıştır.

1990'lı yıllara gelindiğinde uzaktan eğitim sistemi ilk, orta ve yükseköğretim düzeylerine yerleşmeye ve bünyesinde yer alan öğrenci sayısını artırmaya başlamıştır. Elde edilen bu başarılarla birlikte uzaktan eğitim sistemi kabullenilmiş ve ilgi gören bir alan haline gelmiştir. 1990'l1 yılların sonu ve 2000'li yılların başından itibaren, her geçen gün bilgi ve iletişim teknolojisinde yaşanan ilerleme, uzaktan eğitim sisteminin gelişimine imkân sağlamıştır (Bozkurt, 2017, s.86-88; Akdemir, 2011, s.69).

Öğrencilere ve eğitmenlere küresel düzeyde eğitim ve iletişim fırsatı sağlayan uzaktan eğitim sistemine gereken önem verilebilmelidir. $\mathrm{Bu}$ ihtiyacın etkisi COVID-19 sürecinde yoğun olarak hissedilmiştir. COVID-19 sürecinde etkilenen en önemli alanlardan biri de eğitimdir. Yakın geçmişte ütopik karşılanabilecek birtakım değişiklikler, COVID-19 ile birlikte hayatımızın her alanında ve tüm dünyada yaşanmaya başlanmıştır. Bu değişikliklerden biri de aniden uzaktan eğitim sistemine geçiştir ve bununla birlikte eğitime dair bakış açısının yeniden değerlendirilmesi de gün yüzüne çıkmıştır (Bozkurt, 2020, s.112). Tüm dünyada eğitim açısından alınan ilk önlem eğitime ara vermek iken pandeminin hızla yayılması ile eğitime ara vermenin yeterli olmayacağı anlaşılarak uzaktan eğitim sistemine geçiş yapılmıştır. Daha öncesinde bazı üniversitelerde ortak derslerin verilmesinde uzaktan eğitim sistemi benimsenmiş olsa da bütün bölümlerde ve düzeylerde uzaktan eğitime geçiş yapılması ilk kez karşı karşıya kalınmıştır. Bu yeni sisteme ayak uydurmaya çalışan öğrenciler ve akademisyenler ise çeşitli problemlerle karşı karşıya kalmışlardır (Kurnaz ve Serçemeli, 2020, s.264-266).

Uzaktan eğitim sisteminin gelişimi açısından süreye gereksinim duyulması hem öğrencilerin hem de eğitim-öğretim kadrosunun dijital okuryazarlık seviyesinin henüz yeterli düzeyde olmaması, uygulama gerektiren konuların işlenmesinde sıkıntılar yaşanması başlıca sorunlar arasındadır (Odabaş, 2003, s.31). Dahası küresel çapta öğrencilerin internet ortamına taşınması, eğitim alanında yeni eşitsizlikler meydana getirmiştir. Uzaktan eğitim için gerekli olan cihaz eksikliği, internete 
erişimin olmaması, her ebeveynin farklı bilinçte ve güçte olması, ebeveynlerin uzaktan eğitim sürecinde evde eğitim için çocuklarına ayıracak zamanı bulamaması gibi pek çok eşitsizlik söz konusudur. COVID-19 pandemisi ile birlikte tüm dünyada eğitim-öğretim sistemi ani bir değişikliğe uğramış ve uzaktan eğitime ihtiyaç duyulmuştur. Bu dönemde öğrenimin kesintiye uğramaksızın devam etmesi için uzaktan eğitim sisteminin güçlü bir alt yapısının olması gerektiği net bir şekilde anlaşılmıştır. Bu durum uzaktan eğitim sistemine gerekli yatırımların yapılması ve geleneksel eğitim sistemine destek niteliğinde bir uygulama olarak değil tek başına yeterli olacak bir sistem olarak önem verilmesi gerektiğini göstermiştir. Nitekim günümüzde olduğu gibi salgın, afet, zorunlu göç, savaş gibi kriz durumlarında uzaktan eğitim sisteminin ne kadar ehemmiyetli olduğu unutulmamalıdır (Can, 2020, s.17).

\section{Örgütsel Stres}

Literatürde stres hakkında farklı tanımlamalar yapılmıştır. Stres, "insan vücudunun herhangi bir dış talebe verdiği özel olmayan tepkiler bütünü" dür. Stres, "olağanüstü talepler, baskılar veya fırsatlardan dolayı bireyde oluşan gerilim durumudur". Stres, "psikolojik, fiziksel ve davranışsal sonuçlar yaratan koşullar ve uyarıcılara verilen bir cevap"tır. Stres için yapılan bu tanımlama dikkate alındığında stres, bireyin kendinden veya çevresinden kaynaklanan ve üzerinde aşırı fiziksel ya da psikolojik baskı yaratan etkilere gösterdiği bireysel uyum çabasından kaynaklanan, organizmanın tümünü etkileyen bir tepkidir (Eren Gümüştekin ve Öztemiz, 2004, s.64; Soysal, 2009, s.335).

Günümüz toplumunda iş, insanların hayatında önemli bir yere sahiptir. Çünkü insanlar vakitlerinin büyük bir kısmını işte ya da işe dair konuları düşünmekle geçirmektedir. Bu bağlamda çoğu kişinin en çok stres yaşadığı alanlardan biri çalışma yaşamıdır. Kişi, çalışma yaşamında yer alarak hem maddi açıdan hem de sosyal, psikolojik ve kültürel açıdan doyum sağlayarak bedensel ve zihinsel olarak güç harcar. Ancak çalışma yaşamı ve çalışılan örgüt pek çok kişi için mühim bir stres faktörü olabilmektedir. Bu noktada en genel haliyle örgütsel stres, örgüt çalışanlarında fiziksel, psikolojik ya da davranışsal bakımdan farklılıklara yol açan, işin gerekleri ile çalışanların yetenekleri veya 
gereksinimleri arasında uyumsuzluk olması halinde oluşan bir tepki olarak açıklanmaktadır (Yamuç ve Türker, 2015, s.393). Örgütsel stres, çalışanlardan beklenen ile onların becerileri arasındaki dengesizlikten yahut çalışanların işteki performansları ile buna karşılık elde ettikleri gelir arasındaki dengesizlikten kaynaklanabilir. Bunlardan hareketle örgütsel stres, bireyin çalıştı̆̆ örgütteki münasebetleri doğrultusunda, iş yükü, kazancı, çalışma arkadaşları ve yönetimle olan ilişkileri ile bağlantılı bir şekilde ortaya çıkan baskının tümünü ifade eder (Öztürk, 2018, s.14). Neticede örgütsel stres birey ve iş ilişkilerinden kaynaklanan ve bireyi normal işlevlerinden alıkoyan değişiklikler yaratan bir durumdur (Eren Gümüştekin ve Öztemiz, 2004, s.65).

Örgütsel stres, çalışma yaşamında başlıca sorunlardan biridir. Karmaşık iş modelleri, iş yükü, zaman baskısı gibi faktörler modern çalışma yaşamının bileşenleri arasındadır. Bunlar çalışanların stresten etkilenmesi, fiziksel ve psikolojik sorunların yaşanması, devamsızlık artışları ve verimliliğin düşmesi gibi pek çok olumsuzluğa yol açmaktadır. Örgütsel stres yalnızca çalışanların sorunlarla karşı karşıya kalmasına neden olmamakta aynı zamanda örgütsel stresin yol açtığ sorunlar, örgütün varlığını devam ettirmesini ve geleceğini de olumsuz etkilemektedir (Şahin Erbaş, 2019, s.14). Örgütler üzerinde stres, işten tatminsizlik, personel şikâyet ve taleplerinin artması, örgüte bağlılığın azalması, iş ilişkilerinde gerginlik, örgütsel iklimde soğukluk, örgütsel iletişimin zayıflaması, uzayan yemek ve çay molaları, işe devamsızlıklarda artış, hesapta olmayan zaman kayıpları, mal ve hizmetlerin kalitesinde düşüş, bölümler arası işbirliğinin zayıflaması, verimliliğin azalması, kararların etkinliğinin zayıflaması, uyarı ve cezalarda artış, işgücü devrinin yükselmesi, kariyer durgunluğu, iş kazaları, sağlık maliyetlerinde aşırı yükselme, sigorta ödemelerinin miktarında artış, personele ödenen tazminatların artması hile ve sabotaj, aleyhte açılan davaların sayısında artış ve örgütün imajının zayıflaması gibi pek çok olumsuz etki oluşturmaktadır (Yılmaz ve Ekici, 2003, s.8). Örgütsel stres bireylerde, fiziksel, psikolojik ve davranışsal sonuçlar ortaya çıkarmaktadır. Stres, fiziksel olarak sürekli yorgunluk, baş ağrısı, iştahta değişiklik, sivilce, kaslarda gerginlik, bulantı gibi kısa dönemli rahatsızlıklar oluşturabildiği gibi uzun vadede kalp ve damar hastalıkları, migren, kanser, ülser, romatizmal artrit ve alerji gibi önemli 
rahatsızlıklara da yol açabilmektedir. Psikolojik olarak stres depresyon, uyku bozukluğu, sıkıntı, duygusuzluk, kararsızlık gibi rahatsızlıklara neden olabilmektedir. Davranışsal olarak stres sigara, tütün, alkol, ilaç kullanımında artış, uyuşturucu alışkanlığ 1 ve düzensiz beslenme gibi etkiler yaratabilmektedir (Yılmaz ve Ekici, 2003, s.3-7; Eren Gümüştekin ve Öztemiz, 2004, s.65).

Tüm örgütlerde, az ya da çok, görevin niteliğinden, iş arkadaşlarından, ast-üst ilişkilerinden veya iş çevresinden kaynaklı stres ortaya çıkabilmektedir. Örgütteki çalışanları etkileyen çeşitli stres kaynakları olabilir. Bu stres kaynakları; iş yükünün fazlalığı, zamanın sinırlılığı, denetimin sıkı ve yakından olması, yetkinin sorumlulukları karşılamada yetersiz olması, politik havanın güvensizliği, rol belirsizliği, örgüt ve bireyin değerleri arasındaki uyumsuzluk, engellenme, rol çatışması, sorumlulukların yarattığı endişe, çalışma koşulları, insan ilişkileri ve yabancılaşma şeklinde sıralanabilir (Aydın, 2008, s.21).

\section{Yöntem}

\section{Çalışmanın Amacı}

Bu çalışmanın amacı, COVID-19 pandemisi sürecinde bir kamu hizmeti olarak online eğitimin, akademisyenlerin örgütsel stresi üzerindeki etkisini tespit etmektir. Bu amaç doğrultusunda öncelikle teorik bir çerçeve oluşturularak ülkemizde COVID-19 sürecinden, bu sürecin eğitimde meydana getirdiği değişikliklerden, web tabanlı eğitimden ve örgütsel stresten söz edilmiştir. Daha sonra Harran Üniversitesi'nde görev yapmakta bulunan akademisyenlerin web tabanlı eğitime dair tutumlarının ortaya konulması amaçlanmıştır. Bu doğrultuda çalışmanın amacını, çok yönlü bir konu olan COVID-19 sürecindeki kamusal hizmetlerden, online eğitim ve bunun akademisyenlerin örgütsel stresine etkisinin incelenmesi oluşturmaktadır.

\section{Çalışmanın Önemi}

COVID-19 sürecine dair, sürecin başlangıcından günümüze dek literatürde pek çok çalışma bulunmaktadır. COVID-19 ile ilgili yapılan 
çalışmalarda genellikle online eğitim ele alınmıştır. Ancak bu çalışmada, COVID-19 sürecin uzaktan eğitimin akademisyenler üzerinde oluşturduğu stres analiz edilmektedir. Bu husus literatürdeki online eğitime dair yapılan diğer çalışmalardan ayırmaktadır. Bu nedenle akademisyenlerin, konuya dair görüşlerinin ele alınmasının önemli olacağ1 düşünülmüştür. Diğer taraftan yaşamımızda rutin düzeni bozan, belirsizlik yaratan faktörler strese neden olabilmektedir. Bu noktada COVID-19 süreci ile beraber eğitim sisteminde yaşanan ani değişikliğin, akademisyenlerin stresine olan etkisinin incelenmesinin, devam eden sürece ve yeni sisteme katkı sağlayacağı düşünülmektedir.

\section{Çalışmanın Yöntemi}

Yapılan çalı̧̧ma nicel bir araştırma olup araştırmada kullanılacak verilerin toplanması için anket yöntemi kullanılmıştır. Anket hazırlanırken literatürdeki çalışmalar göz önünde bulundurulmuştur.

Çalışmada kullanılan anket üç bölümden oluşmaktadır. Birinci bölüm; ankete katılan akademisyenlerin demografik yapılarının öğrenilmesi amaciyla yedi soru içermektedir. İkinci bölümde ise Erdoğan, Bayram ve Deniz (2007) tarafından geliştirilen "Web tabanlı öğretim tutum ölçeği" referans alınmıştır. Ölçek 25 sorudan ve iki farklı alt boyuttan oluşmaktadır. Alt boyutlar sırasıyla 17 sorudan oluşan "web tabanlı öğretimin etkililik boyutu" ve sekiz sorudan oluşan "web tabanlı öğretime karşı direnme boyutu" şeklinde ifade edilmiştir. Söz konusu anket öğrencilere yönelik hazırlanmıştır. $\mathrm{Bu}$ nedenle sorular akademisyenlerin tutumlarını ölçmeye yönelik uyarlanmıştır. Anket beşli likert ölçekten oluşmuş ve önermelere verilen cevaplar "1.tamamen katılıyorum" dan "5.tamamen katılmıyorum" aralığında cevaplanmıştır. Üçüncü bölümde ise Theorell ve arkadaşları (1988) tarafından geliştirilen ve araştırmacılar tarafından Türkçeye uyarlanan "Örgütsel stres ölçeği" referans alınmıştır. Bu ölçek, 11 sorudan oluşmakta olup, "İş yükü", "Beceri kullanımı", "Karar serbestliği" ve "Sosyal destek" olmak üzere dört alt boyuttan oluşmaktadır. Ölçek soruları online eğitim sürecine uygun olarak uyarlanmıştır. Bu bölümdeki anket soruları da beşli likert ölçekten oluşmuş ve önermelere verilen cevaplar "1. hiçbir zaman" dan “5. her zaman" aralığında cevaplanmıştır. 
Anket uygulaması Harran Üniversitesi'nde 2020-2021 eğitim öğretim y1lı bahar döneminde görev yapmakta olan 278 akademisyene online olarak uygulanmıştır. Elde edilen veriler için SPSS (Statistical Package for the Social Sciences) programıla gerekli analizler yapılmıştır ve elde edilen sonuçlar tablolar halinde yorumlanmıştır.

\section{Çalışmanın Evreni, Örneklemi ve Sınırlılıkları}

Çalışmanın evrenini Harran Üniversitesi'nde 2020-2021 eğitim-öğretim yılı bahar döneminde görev yapmakta olan öğretim elemanları oluşturmaktadır. Harran Üniversitesi verilerine göre bu dönemde üniversite bünyesinde görev yapmakta olan 1079 öğretim elemanı bulunmaktadır. Cohen, Manion ve Morrison'a göre evreni 1000 kişiden oluşan bir çalışma için örneklem sayısı \%95 güven ile en az 278 kişiden; evreni 3000 kişiden oluşan bir çalışma için örneklem sayısı \%95 güven ile en az 341 kişiden oluşmalıdır (Yıldız, 2017, s.442). Yapılan çalışmanın evreni 1079 kişi ile 1000 kişilik evrene daha yakın olduğu için çalışmanın örneklemi Harran Üniversitesi'nde 2020-2021 eğitim-öğretim yılı bahar döneminde görev yapmakta olan ve kolayda örneklem yöntemi ile seçilmiş olan 278 akademisyenden oluşmaktadır. Buna istinaden Harran Üniversitesi'nde görev yapmakta olan akademisyenlere 278 adet anket formu e-posta yoluyla uygulanmaya çalışılmıştır. Çalışma, zaman ve maliyet kısıtları nedeniyle araştırma süreci döneminde Harran Üniversitesi'nde görev yapmakta olan akademisyenlerle sınırlı tutulmuştur. Verilerin sadece bir ilden ve tek bir kurumdan toplanmış olması çalışmanın en önemli kısıtını oluşturmaktadır.

\section{Etik Kurul Onayı}

"COVID-19 Sürecinde Online Eğitimin Akademisyenlerin Örgütsel Stresine Etkisi: Harran Üniversitesi Örneği" konulu çalışmamız ile ilgili Harran Üniversitesi Sosyal ve Beşeri Bilimler Etik Kurulu'na başvurulmuş olup, 09.02.2021 tarih ve 2021/24 sayılı karar ile etik açıdan çalışmanın yapılmasının uygun olduğuna oy birliği ile karar verilmiştir.

Ayrıca etik kurul onayından sonra Sağlık Bakanlığın web sitesi aracılığıyla Sağlık Hizmetleri Genel Müdürlüğü bünyesinde kurulmuş 
olan COVID-19 Bilimsel Araştırma Değerlendirme Komisyonu'ndan da gerekli izin alınmıştır.

\section{Çalışmanın Modeli ve Hipotezi}

Kuramsal çalışma sonrasında, çalışmanın amacına uygun bir model oluşturulmuştur.

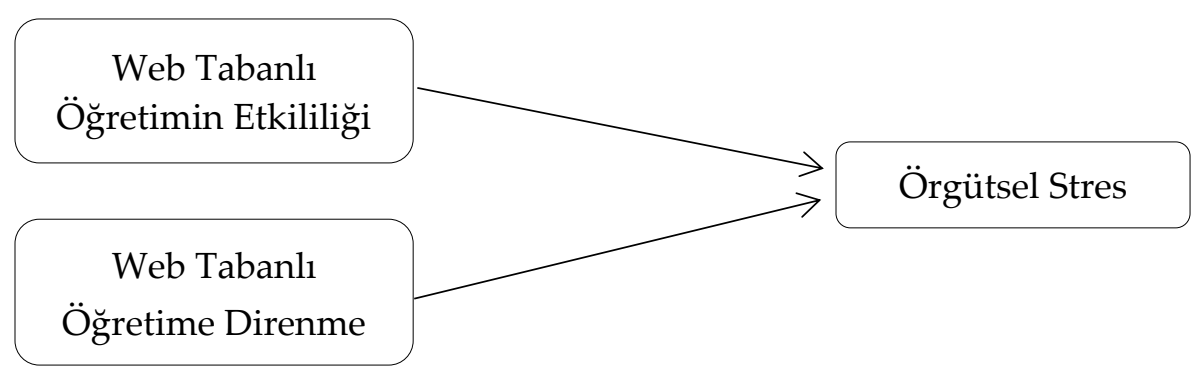

Şekil 1. Çalışmanın Modeli

Çalışmanın modeli ve amacı doğrultusunda geliştirilen hipotezler aşağıda belirtilmiştir:

Tablo 1. Çalışma Hipotezleri

\begin{tabular}{|c|c|}
\hline Hipotez & Açıllama \\
\hline H1 & Web tabanlı öğretimin akademisyenlerin örgütsel stres üzerinde anlamlı bir etkisi vardır. \\
\hline H1a & $\begin{array}{l}\text { Web tabanlı öğretimin etkililiği boyutunun akademisyenlerin örgütsel stresi üzerinde anlamlı } \\
\text { bir etkisi vardır. }\end{array}$ \\
\hline H1b & $\begin{array}{l}\text { Web tabanlı öğretime karşı direnme boyutunun akademisyenlerin örgütsel stresi üzerinde } \\
\text { anlamlı bir etkisi vardır. }\end{array}$ \\
\hline H2 & Web tabanlı öğretim ve akademisyenlerin örgütsel stresi arasında anlamlı bir ilişki vardı. \\
\hline H2a & $\begin{array}{l}\text { Web tabanlı ögretimin etkililiği boyutu ve akademisyenlerin örgütsel stresi arasında anlamlı } \\
\text { bir ilişki vardır. }\end{array}$ \\
\hline $\mathrm{H} 2 \mathrm{~b}$ & $\begin{array}{l}\text { Web tabanlı öğretimine karşı direnme boyutu ve akademisyenlerin örgütsel stresi arasında } \\
\text { anlamlı bir ilişki vardır. }\end{array}$ \\
\hline
\end{tabular}

\section{Bulgular}

Bu bölümde çalışmanın güvenilirlik ve geçerlilik analizleri, katılımcıların demografik bilgileri için yapılan frekans analizlerinin sonuçları verilmiştir. Esas olarak çalışmanın hipotezlerine uygun olarak web tabanlı öğretimin, örgütsel strese etkisinin ölçülebilmesi ve web tabanlı 
öğretim ile örgütsel stres arasında anlamlı bir ilişkinin olup olmadığının saptanması amaçlanmıştır. Bu doğrultuda öncelikli olarak verilerin dağılımının parametrik olup olmadığını (normal dağılım) belirlemek için Shapiro-Wilk Testi yapılmış ve verilerin normal dağıldığı tespit edilmiştir. $\mathrm{Bu}$ nedenle bir bağımsız bir bağımlı değişken arasındaki etkiyi analiz etmek için basit regresyon analizi yapılmıştır. Daha sonra web tabanlı öğretim ile örgütsel stres arasındaki ilişkiyi analiz edebilmek adına hipotezler doğrultusunda korelasyon analizi yapılmıştır. Çalışmanın hipotezleri bu bölümde test edilmiş ve bu hipotezlerin durum özetlerini gösteren tablo da bu bölümde paylaşılmıştır.

\section{Güvenilirlik Analizi}

Çalışmada kullanılan ölçeğin güvenilirliğini belirleyebilmek için Cronbach's Alpha testinden faydalanılmıştır. Cronbach Alpha Katsayısının değerlendirilmesi şu şekildedir (Arslan, 2020, s.3394):

- $\quad \alpha<0,40$ : Ölçek güvenilir değil,

- $0,41<\alpha<0,60$ : Ölçek düşük düzeyde güvenilir,

- $0,61<\alpha<0,80$ : Ölçek oldukça güvenilir,

- $\quad 0,81<\alpha<1,00$ : Ölçek yüksek derecede güvenilirdir.

Cronbahch's Alpha analizi sonucu elde edilen güvenilirlik testinin sonucu aşağıdaki tabloda verilmiştir:

Tablo 2. Güvenilirlik Analizi

\begin{tabular}{lll}
\hline Ölçek & Soru Sayısı & Cronbach's Alpha Değeri \\
\hline Web Tabanlı Öğretim & 25 &, 813 \\
Örgütsel Stres & 11 &, 773 \\
\hline
\end{tabular}

Yapılan analiz sonucu web tabanlı öğretim ölçeğinin güvenilirlik analizi 0,813 gibi yüksek bir oranda; örgütsel stres ölçeğinin güvenilirlik değeri de 0,773 oranında açıklanmıştır. Dolayısıyla hem web tabanlı öğretim ölçeğinin hem örgütsel stres ölçeğinin güvenilir olduğu tespit edilmiştir. 


\section{Faktör Analizi}

Çalışmada yer alan her iki ölçeğe ayrı ayrı faktör analizi uygulanmıştır. İlk olarak web tabanlı öğretim düzeyini ölçmeye yönelik değişkenlerle, daha sonra da örgütsel stres düzeyini ölçmeye yönelik değişkenlere faktör analizi uygulanmıştır.

\section{Web Tabanlı Öğretim Ölçeğinin Faktör Analizi}

Tablo 3. Web Tabanlı Öğretim Ölçeğine İlişkin KMO Örneklem Yeterliliği Ölçeği ve Bartlett Küresellik Testi Değeri

\begin{tabular}{lll}
\hline KMO &, 925 & \\
\hline \multirow{3}{*}{ Bartlett Küresellik Testi } & Yaklaşık Ki-Kare & 4251,500 \\
& Df. & 300 \\
& Sig. &, 000 \\
\hline
\end{tabular}

KMO (örneklem yeterliliği istatistiği) verilerin faktör analizi için yeterli olup olmadığını ölçen testtir. KMO testinin değeri 0 ile 1 aralığında olmalıdır ve bu değer 1'e yaklaştıkça örneklemin faktör analizine uygunluğu artmaktadır. KMO'su 0,8'in üzerinde olan değerler mükemmel kabul edilmektedir (Yaşlığlu, 2017, s.75-76). Tablo 3'te görüldüğü üzere KMO değeri 0,925 ile faktör analizi yapılması için uygun bir değerdedir. Yine aynı nedenle yapılan Bartlett testi sonucu Significance $=0,000$ olduğu ve $p<0.05$ koşulunu sağladığ için verilerin faktör analizi için uygun olduğuna karar verilmiştir. 
Tablo 4. Web Tabanlı Öğretim Ölçeğine İlişkin Faktör Analizi

WTÖ (Web tabanlı öğretim) Ölçeği (Faktör ve Değişkenler)

\begin{tabular}{|c|c|c|}
\hline Faktör 1: Web Tabanlı Öğretimin Etkililiği Boyutu & 1 & 2 \\
\hline 1. WTÖ'i meslektaşlarıma tavsiye ederim. & ,686 & \\
\hline 2. WTÖ sorumluluk duygusunu geliştirmektedir. & ,599 & \\
\hline 3. WTÖ klasik eğitim kadar etkilidir. & ,672 & \\
\hline 4. Yükseköğretimde WTÖ uygulamalarına geçilmelidir. & ,659 & \\
\hline 5. WTÖ’́de öğrencilerle iletişim kurabilmekteyim. & ,636 & \\
\hline 6. WTÖ "eğitim sorununa" alternatif bir çözümdür. & 630 & \\
\hline 7. WTÖ yaşam boyu öğrenmeyi sağlar. & ,739 & \\
\hline 8. WTÖ'in yaygınlaşması toplum için yararlıdır. & ,756 & \\
\hline 9. Verdiğim WTÖ'e güvenmekteyim. & ,708 & \\
\hline 10. WTÖ öğrencilerin kendi hızlarına uygun öğrenme fırsatı sağlamaktadır. & ,781 & \\
\hline 11. WTÖ öğrencileri araştırmaya teşvik etmektedir. & ,726 & \\
\hline 12. WTÖ'de yeterli rehberlik hizmeti verilebilmektedir. & ,706 & \\
\hline 13. WTÖ'de yeterli geribildirim alabilmekteyim. & ,713 & \\
\hline 14. WTÖ önümüzdeki yıllarda kaçınılmaz olacaktır. & ,593 & \\
\hline 15. WTÖ öğrencilerin kendilerine olan özgüvenlerini arttırmaktadır. & ,747 & \\
\hline 16. WTÖ’de öğrenciler düşüncelerini özgürce ifade edebilmektedir. & ,740 & \\
\hline 17. WTÖ üniversite-sanayi iş birliğini teşvik etmektedir. & ,681 & \\
\hline Faktör 2: Web Tabanlı Öğretime Karşı Direnme Boyutu & 1 & 2 \\
\hline 18. Web üzerinden ders anlatmak sıkıcıdır. & & ,787 \\
\hline 19. WTÖ’de öğrenilen konu çabuk unutulmaktadır. & & ,765 \\
\hline 20. WTÖ'in sıkıcı olduğunu düşünmekteyim. & & 839 \\
\hline 21. WTÖ'de ortaya çıkan teknik sorunlar beni sinirlendirmektedir. & & ,646 \\
\hline 22. WTÖ takım çalışmasını olumsuz yönde etkilemektedir. & & ,773 \\
\hline 23. WTÖ zaman kaybıdır. & & 643 \\
\hline 24. WTÖ sosyal yönü zayıflatmaktadır. & & 649 \\
\hline 25. WTÖ yüzünden kendime yeterli zaman ayıramamaktayım. & & ,643 \\
\hline
\end{tabular}

Tablo 5. Faktör Analizi Sonrası Etkililik ve Direnme Boyutunun Güvenilirlik Analizi

\begin{tabular}{lcc}
\hline Boyut & Soru Sayısı & Cronbach's Alpha Değeri \\
\hline WTÖ Etkililik Boyutu & 17 &, 939 \\
WTÖ Direnme Boyutu & 8 &, 881 \\
\hline
\end{tabular}

Web tabanlı öğretim ölçeğinin faktör analizi Tablo 4 'te verilmiştir. Analiz sonucunda, web tabanlı öğretim ölçeğinde yer alan ifadelerin web tabanlı öğretimin etkililiği ve web tabanlı öğretime karşı direnme olmak üzere iki ayrı boyutta toplandığı görülmüştür. Sonuçların, ölçeğin orijinali ile aynı boyutlara toplandığı tespit edilmiştir.

Ayrıca faktör analizi sonrasında araştırmanın amacına uygun olarak hipotezleri test edebilmek adına etkililik ve direnme boyutuna ilişkin güvenilirlik analizi yapılmıştır. Tablo 5 'ten de anlaşıldığı üzere elde 
edilen sonuçlara göre her iki boyutun da yüksek derecede güvenilir olduğu sonucuna ulaşılmıştır.

\section{Örgütsel Stres Ölçeğinin Faktör Analizi}

Tablo 6. Örgütsel Stres Ölçeğine İlişkin KMO Örneklem Yeterliliği Ölçeği ve Bartlett Küresellik Testi Değeri

\begin{tabular}{lll}
\hline KMO &, 704 & \\
\hline & Yaklaşık Ki-Kare & 1025,003 \\
Bartlett Küresellik Testi & Df. & 55 \\
& Sig. &, 000 \\
\hline
\end{tabular}

Tablo 6'da görüldüğü üzere KMO değeri 0,704 ile faktör analizi yapılması için uygun bir değerdedir. Ayrıca, Bartlett testi sonucu Significance $=0,000$ olduğu ve $p<0.05$ koşulunu sağladığı için verilerin faktör analizi için uygun olduğuna karar verilmiştir.

Tablo 7. Örgütsel Stres Ölçeğine İlişkin Faktör Analizi

\begin{tabular}{|c|c|c|c|c|}
\hline \multirow{2}{*}{$\begin{array}{l}\text { Örgütsel Stres Ölçeği (Faktör ve Değişkenler) } \\
\text { Faktör 1: İş Yükü }\end{array}$} & \multicolumn{4}{|c|}{ Faktör Yük Değerleri } \\
\hline & 1 & 2 & 3 & 4 \\
\hline 1. Uzaktan eğitim sürecinde çok hızlı çalışmak zorundayım. & 853 & & & \\
\hline 2. Uzaktan eğitim sürecinde çok yoğun çalışmak zorundayım. &, 864 & & & \\
\hline 3. Yaptığım iş teknolojik açıdan çok fazla çaba gerektirir. & 633 & & & \\
\hline 4. Uzaktan eğitim sebebiyle her şeyi yapmak için yeterli zamanım var. & 651 & & & \\
\hline Faktör 2: Beceri Kullanımı & 1 & 2 & 3 & 4 \\
\hline 5. Bu süreçte yaptığım iş yeni şeyler öğrenmeme imkân sağlamaktadır. & & ,579 & & \\
\hline $\begin{array}{l}\text { 6. Bu süreçte yaptığım iş teknolojik olarak üst düzeyde beceri ve uzmanlık } \\
\text { istemektedir. }\end{array}$ & & ,854 & & \\
\hline 7. Tekrar ve tekrar aynı şeyleri yapmak zorunda kalmaktayım. & &, 510 & & \\
\hline Faktör 3: Karar Serbestliği & 1 & 2 & 3 & 4 \\
\hline 8. Bu süreçte işimde nasıl çalışacağımın kararını kendim verebilmekteyim. & & & 892 & \\
\hline 9. Bu süreçte işimde ne yapacağımın kararını kendim verebilmekteyim. & & & ,890 & \\
\hline Faktör 4: Sosyal Destek & 1 & 2 & 3 & 4 \\
\hline $\begin{array}{l}\text { 10. Uzaktan eğitim sürecinde meslektaşlarım ile teknolojik bilgi açısından } \\
\text { birbirimizi desteklemekteyiz. }\end{array}$ & & & & ,787 \\
\hline 11. Meslektaşlarım ile çalışmaktan zevk alırım. & & & & ,782 \\
\hline
\end{tabular}

Tablo 8. Faktör Analizi Sonrası İş Yükü, Beceri Kullanımı, Karar Serbestliği ve Sosyal Destek Boyutunun Güvenilirlik Analizi

\begin{tabular}{lcc}
\hline Boyut & Soru Sayısı & Cronbach's Alpha Değeri \\
\hline ÖS İş Yükü Boyutu & 4 &, 729 \\
ÖS Beceri Kullanımı Boyutu & 3 &, 711 \\
ÖS Karar Serbestliği Boyutu & 2 &, 882 \\
ÖS Sosyal Destek Boyutu & 2 &, 751 \\
\hline
\end{tabular}


Örgütsel stres ölçeğinin faktör analizi Tablo 7'de verilmiştir. Analiz sonucunda, tanımlanan faktör yapısının Demiral ve arkadaşlarının tanımlamış olduğu faktör yapısı ile benzerlik göstererek, iş yükü, beceri kullanımı, karar serbestliği ve sosyal destek alt boyutlarına ayrıldığını ve yine Demiral ve arkadaşlarının çalışmalarına paralel nitelikte ifadelerin aynı alt boyutlarda toplandığı tespit edilmiştir (Demiral, 2007).

Ayrıca faktör analizi sonrası örgütsel stres ölçeğinin alt boyutlarının güvenilirlik analizi yapılmıştır. Tablo 8 'den de anlaşıldığ boyutun da güvenilir olduğu sonucuna ulaşılmıştır.

\section{Demografik bulgular}

Tablo 9. Katılımcılarn Demografik Bilgileri

\begin{tabular}{cccc}
\hline Demografik Bilgiler & & Sayı & Yüzde \\
\hline \multirow{2}{*}{ Cinsiyet } & Kadın & 58 & 20.9 \\
& Erkek & 220 & 79.1 \\
\hline \multirow{3}{*}{ Yaş } & $22-28$ & 18 & 6.5 \\
& $29-35$ & 55 & 19.8 \\
& $36-42$ & 51 & 18.3 \\
& $43-49$ & 55 & 19.8 \\
& $50-56$ & 71 & 25.5 \\
& $57-63$ & 26 & 9.4 \\
\multirow{2}{*}{ Medeni Durum } & 64 ve üstü & 2 & 0.7 \\
& Evli & 226 & 81.3 \\
& Bekâr & 52 & 18.7 \\
\hline \multirow{2}{*}{ Akademik Unvan } & Araştırma Görevlisi & 31 & 11,2 \\
& Öğretim Görevlisi & 93 & 33,5 \\
& Doktor Öğretim Üyesi & 55 & 19,8 \\
& Doçent Doktor & 41 & 14,7 \\
& Profesör & 58 & 20,9 \\
\hline \multirow{2}{*}{ Yönetsel Göreviniz Var Mi? } & Evet & 122 & 43.9 \\
& Hayır & 156 & 56.1 \\
\hline \multirow{2}{*}{ Hizmet Süresi } & $0-5$ & 71 & 25,5 \\
& $6-11$ & 63 & 22,7 \\
& $12-17$ & 17 & 6,1 \\
& $18-23$ & 37 & 13,3 \\
& $24-29$ & 76 & 27,3 \\
& 30 ve üstü & 14 & 5,0 \\
\hline \multirow{2}{*}{ Ders Yükü } & Ders vermiyorum & 23 & 8,3 \\
& $0-5$ & 17 & 6,1 \\
& $6-11$ & 35 & 12,6 \\
& $12-17$ & 61 & 21,9 \\
& $18-23$ & 54 & 19,4 \\
& 24 ve üstü & 88 & 31,7 \\
\hline
\end{tabular}


Katılımcıların demografik özellikleri Tablo 9'da verilmiştir. Tabloda görüldüğü üzere katılımcıların \%79,1 gibi büyük bir çoğunluğu erkeklerden oluşurken, \%20,9'u kadınlardan oluşmaktadır. Katılımcıların \%81,3 ile önemli bir çoğunluğu evli iken \%18,7'si bekârdır.

Yaş aralıklarına baktığımızda oranların birbirine oldukça yakın olduğu görülmektedir. En fazla \%25,5 ile "50-56 yaş" aralığında katılımc1 yer alırken bu oranı \%19,8 ile eşit bir şekilde "43-49 yaş" aralığındaki ve "29-35 yaş" aralığındaki akademisyenler takip etmektedir. "36-42 yaş" aralığındaki akademisyenlerin oranı da birbirine yakın olup \%18,3'tür. Bunu sırasılyla \%9,4 ile "57-63 yaş" aralığındaki akademisyenler ve \%6,5 ile "22-28 yaş" aralığındaki akademisyenler takip etmektedir. Yaş aralığ açısından en düşük orana sahip grup ise \%0,7 ile "64 yaş ve üstü" akademisyenlerdir.

Katılımcıların akademik unvan oranlarının dağılımı incelendiğinde \%33,5 ile en fazla öğretim görevlilerinin yer aldığını görmekteyiz. Bu oranı \%20,9 ile profesörler, \%19,8 ile doktor öğretim üyeleri, \%14,7 ile doçent doktorlar takip ederken en az orana sahip olan grup \%11,2 ile araştırma görevlileridir. Ancak oransal olarak bakıldığında araştırma görevlilerin diğer gruplarla aralarında çok büyük bir fark görünmemektedir.

Katılımciların \%56,1'lik oranının yönetsel bir görevi yok iken, \%43,9'luk oranının yönetsel görevi bulunmaktadır. Yönetsel görevler açısından oranlar birbirine çok yakındır.

Katılımcların hizmet süreleri birbirine yakın olmakla birlikte \%27,3'ü “24-29 yıl” aralığında, \%25,5'i “0-5 yıl” aralığında, \%22,7' si “6-11 yıl" aralığında hizmet süresine sahiptir. Hizmet süresi açısından daha düşük oranlara sahip aralıklar ise sırasıyla \%13,3 ile "18-23 yıl" aralığı, $\% 6,1$ ile "12-17 yıl" aralığı ve en düşük \%5 ile "30 ve üstü yıl" aralığıdır.

Ders yükü açısından katılımcıların \%31,7'sinin "24 ve üstü saat" aralığında ders yükü bulunmaktadır. Katılımcıların \%21,9'unun "12-17 saat" aralığında, \%19,4'ünün "18-23 saat" aralığında ders yükü vardır. $\mathrm{Bu}$ durumdan da anlaşıldığı üzere Harran Üniversitesi öğretim elemanlarının önemli bir çoğunluğunun ders yükünün fazla olduğu sonucuna ulaşılır. Bu oranları nispeten daha az olarak sırası ile $\% 12,6$ katılımcının "6-11 saat" aralığında, \%8,3'ünün ders vermediği, \%6,1'inin "0-5 saat" aralığında ders yüküne sahip olması takip etmektedir. 
Dolayısıyla daha az orandaki katılımcıların ders yükü daha az iken katılımcların çoğunluğunu oluşturan oranın daha fazla ders yüküne sahip olduğu söylenebilir.

\section{Regresyon Analizi}

Bir değişkenin (bağımlı) diğer değişken ya da değişkenler (bağımsız) tarafından nasıl açıklandığını gösteren analiz, regresyon analizi olarak adlandırılmaktadır. Regresyon analizinde, birden fazla bağımsız değişken kullanılabilmektedir. Bu analiz araştırmacıya, ilişkinin yönünü, şeklini, bilinmeyen değerlere ait tahminleri vermektedir (Durmuş, Yurtkoru ve Çinko, 2016, s.154).

Web tabanlı öğretim ölçeğine ve örgütsel stres ölçeğine uyarlama yapıldığı için söz konusu bu iki ölçek için de ölçeklerin güvenilirliklerini ve geçerliliklerini yeniden test edebilmek adına faktör analizi yapılmıştır. Analiz sonucunda ölçeklerin orijinalleri ile paralel nitelikte olduğu dolayısıyla uyarlanan ölçeklerin geçerli olduğu sonucuna ulaşılmıştır. Ancak çalışmanın amacına uygun olarak örgütsel stres ölçeğinin alt boyutları analize tabi tutulmayacak ve web tabanlı öğretim ölçeğinin etkililik ve direnme boyutlarının örgütsel stres ölçeğinin genel toplam puanı üzerinden etkisine bakılacaktır. Bu nedenle çalışmanın bu bölümünde, 278 anket üzerinde basit doğrusal regresyon analizi yapılacak ve hipotezlerin sonuçları test edilecektir.

Tablo 10. Genel Regresyon Modeli Özetleri ve Anova

\begin{tabular}{|c|c|c|c|c|c|c|c|c|c|c|}
\hline $\begin{array}{l}\bar{\Xi} \\
\bar{\Xi} \\
\end{array}$ & 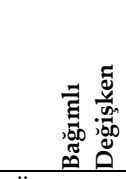 & $\simeq$ & $\approx$ & 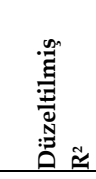 & 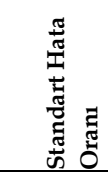 & 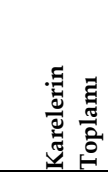 & $\bar{n}$ & 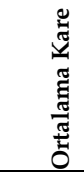 & 上 & 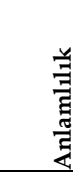 \\
\hline $\begin{array}{l}1 \\
\text { (H1a) }\end{array}$ & $\begin{array}{l}\text { Örgütsel } \\
\text { Stres }\end{array}$ & 108 & ,012 & ,008 & ,53433 & ,933 & 1 & ,933 & 3,268 & ,072 \\
\hline Kalintr & & & & & & 78,800 & 276 & 286 & & \\
\hline Toplam & & & & & & 79,734 & 277 & & & \\
\hline 2 & $\begin{array}{l}\text { Örgütsel } \\
\text { Stres }\end{array}$ & 133 & ,018 & ,014 & ,55273 & 1,405 & 1 & 1,405 & 4,951 & ,027 \\
\hline Kalinte & & & & & & 78,328 & 276 & 284 & & \\
\hline Toplam & & & & & & 79,734 & 277 & & & \\
\hline
\end{tabular}

Bağımsız Değişkenler: Etkililik ve Direnme 
Model 1'e (H1a) göre, web tabanlı öğretimin etkililiği boyutunun, örgütsel stres üzerindeki etkisine ilişkin regresyon analizinde $p$ değerinin 0,072>0,05 olması nedeniyle, regresyon modelinin anlamlı bir sonucu bulunmamaktadır. Dolayısıyla web tabanlı öğretimin etkililik boyutunun örgütsel stres üzerinde anlamlı bir etkisi yoktur. Bu nedenle H1a reddedilmiştir.

Model 2'ye (H1b) göre, web tabanlı öğretime karşı direnme boyutunun, örgütsel stres üzerindeki etkisine ilişkin regresyon analizinde $\mathrm{p}$ değerinin $0,027<0,05$ olması, regresyon modelinin anlamlı bir sonucu olduğunu göstermektedir. Bu modelde bağımlı değişkenin, bağımsız değişken (direnme boyutu) ile ilişkisinin 0,108 olduğu görülmektedir. Aynı zamanda, bağımsız değişkenin bağımlı değişkeni açıklama derecesi (varyans) 0,012'dir. Diğer bir ifadeyle web tabanlı öğretime direnme boyutunun örgütsel stresi tanımlama derecesinin $\% 13,3$ olduğu görülmektedir.

Tablo 11. Genel Regresyon Katsayıları

\begin{tabular}{lllllll}
\hline Model & $\begin{array}{l}\text { Bağımlı } \\
\text { Değişken }\end{array}$ & $\begin{array}{l}\text { Bağımsız } \\
\text { Değişken }\end{array}$ & $\begin{array}{l}\text { Standardize } \\
\text { Olmayan } \\
\text { Katsayılar } \\
\text { B }\end{array}$ & $\begin{array}{l}\text { Standardize Olmuş } \\
\text { Katsayılar } \\
\text { Beta }\end{array}$ & T Değeri & Anlamlılık \\
\hline 1 & Örgütsel Stres & (Sabit) & 3,561 & & 27,616 &, 000 \\
(H1a) & Etkililik & &,- 108 & $-1,808$ &, 072 \\
2 & Örgütsel Stres & (Sabit) & 3,105 & & 28,710 &, 000 \\
(H1b) & & Direnme & &, 133 & 2,225 &, 027 \\
\hline
\end{tabular}

(Model 2) Örgütsel Stres: 3,105+ 0,133 (Direnme)

Beta değerinin 1'e yakın olması ve p değerinin $0.05^{\prime}$ ten küçük olması modele anlamlı bir katkı sağlamaktadır. Buna göre, tablo 11'de görüldüğü üzere web tabanlı öğretim boyutlarından, direnme boyutunun beta değeri 0.133 , p değeri $0.027^{\prime}$ dir. Bu sebeple web tabanlı öğretim boyutlarından olan direnmenin, örgütsel stres üzerinde pozitif ve anlamlı derecede etkili olduğu sonucuna varılmaktadır. Fakat web tabanlı öğretimin bir diğer boyutu olan etkililik $(\Omega=-0.108, p=0.072)$ boyutunun örgütsel stres üzerinde istatistiksel olarak anlamlı bir etkisi olmadığı görülmektedir. 
Tüm bunlarla birlikte H1a hipotezi reddedilirken, H1b hipotezi kabul edilmiştir. Diğer bir ifadeyle, web tabanlı öğretimin akademisyenlerin örgütsel stresi üzerinde anlamlı bir etkisi vardır.

\section{Korelasyon Analizi}

Değişkenlerin, bağımlı mı bağımsız mı olduğu dikkate alınmaksızın aralarındaki ilişkinin yönü ve derecesini belirlemek amacı ile yapılan istatistiki analiz korelasyon analizi olarak adlandırılmaktadır (Durmuş, Yurtkoru ve Çinko, 2016, s.143). Bu bağlamda, çalışma modeline yer alan web tabanlı öğretimin etkililiği, web tabanlı öğretime karşı direnme ve örgütsel stres değişkenleri arasındaki ilişkiyi ölçmek adına korelasyon analizi gerçekleştirilmiştir.

Tablo 12. Korelasyon Analizi Sonucu

\begin{tabular}{lllll}
\hline \multirow{3}{*}{ Direnme } & & Direnme & Etkililik & Örgütsel Stres \\
& Pearson Correlation & 1 &,- 429 &, $133^{*}$ \\
& Sig. (2-tailed) & &, 000 &, 027 \\
& $\mathrm{~N}$ & 278 & 278 & 278 \\
\hline \multirow{3}{*}{ Etkililik } & Pearson Correlation &,- 429 & 1 &,- 108 \\
& Sig. (2-tailed) &, 000 & &, 072 \\
\hline \multirow{3}{*}{ Örgütsel Stres } & $\mathrm{N}$ & 278 & 278 & 278 \\
& Pearson Correlation &, $133^{*}$ &,- 108 & 1 \\
& Sig. (2-tailed) &, 027 &, 072 & \\
\hline
\end{tabular}

*. Correlation is significant at the 0.05 level (2-tailed).

Çalışmada web tabanlı öğretime karşı direnme, web tabanlı öğretimin etkililiği ve örgütsel stres arasındaki ilişkiyi belirlemek için yapılan korelasyon analizi sonucunda etkililik ve örgütsel stres arasındaki ilişki baz alındığında sig=0,072 ile 0,05'ten büyük olduğu için bu iki değişken arasında anlamlı bir ilişki görülmemektedir. Direnme ve örgütsel stres arasındaki ilişkiye bakıldığında ise elde edilen sig. (p) değerinin $0,05^{\prime}$ ten küçük olma $(\mathrm{P}<, 05)$ koşulunu sağladığı için, bu iki değişken arasında istatiksel açıdan anlamlı bir ilişki olduğu sonucu elde edilmiştir. Pearson Korelasyon katsayısının 0,133 olmasından dolayı direnme ile örgütsel stres arasında pozitif ve zayıf bir ilişkinin olduğu sonucuna ulaşılmaktadır. 
$\mathrm{Bu}$ bağlamda $\mathrm{H} 2 \mathrm{a}$ hipotezi reddedilirken, $\mathrm{H} 2 \mathrm{~b}$ hipotezi kabul edilmiştir. Diğer bir ifadeyle, web tabanlı öğretim ile akademisyenlerin örgütsel stresi arasında anlamlı bir ilişki olduğu sonucuna ulaşılmıştır. Fakat aralarındaki ilişkinin pozitif ve zayıf bir ilişki olduğu tespit edilmiştir.

\begin{tabular}{lll} 
Tablo 13. Çalışmanın Hipotezlerinin Durum Özetleri & \\
\hline No & Hipotez & Durum \\
\hline H1 & $\begin{array}{l}\text { Web tabanlı ögretimin akademisyenlerin örgütsel stres üzerinde anlamlı bir etkisi } \\
\text { vardır. }\end{array}$ & KABUL \\
H1a & $\begin{array}{l}\text { Web tabanlı öğretimin etkililiği boyutunun akademisyenlerin örgütsel stresi üzerinde } \\
\text { anlamlı bir etkisi vardır. } \\
\text { Web tabanlı öğretime karşı direnme boyutunun akademisyenlerin örgütsel stresi } \\
\text { üzerinde anlamlı bir etkisi vardır. }\end{array}$ & RED \\
H2 & $\begin{array}{l}\text { Web tabanlı öğretim ve akademisyenlerin örgütsel stresi arasında anlamlı bir ilişki } \\
\text { vardı } \\
\text { Web tabanlı öğretimin etkililiği boyutu ve akademisyenlerin örgütsel stresi arasında } \\
\text { H2a }\end{array}$ & KABUL \\
H2b & $\begin{array}{l}\text { Web tabanlı öğretimine karşı direnme boyutu ve akademisyenlerin örgütsel stresi } \\
\text { arasında anlamlı bir ilişki vardır. }\end{array}$ & KABUL \\
\hline & & KABUL
\end{tabular}

\section{Tartışma ve Sonuç}

Çalışmada COVID-19 sürecinde uzaktan eğitimin akademisyenlerin örgütsel stresi üzerindeki etkisinin incelenmesi maksadıyla öncelikli olarak kuramsal bir çerçeve oluşturulmuştur. Ardından çalışmanın amacı doğrultusunda Harran Üniversitesi'nde görev yapmakta olan akademisyenlerin konuya dair görüşlerinin tespit edilebilmesi için hazırlanan anket kolayda örnekleme yöntemi ile online olarak Harran Üniversitesi'nde 2020-2021 eğitim-öğretim yılı bahar döneminde görev yapmakta olan 278 akademisyene gönüllülük esasına göre uygulanmıştır. Çalışmanın uygulama bölümünde ise ileri sürülen hipotezler doğrultusunda gerekli analizler yapılmış, elde edilen veriler incelenmiş ve yorumlanmıştır.

Çalışmada verilerin analizi için SPSS paket programı kullanılmıştır. İlk olarak verilerin normal dağılıp dağılmadığını test etmek adına Shapiro-Wilk Testi yapılmıştır. Verilerin tüm ölçekler için normal dağıldığ1 sonucuna ulaşılmıştır. Daha sonra araştırmada kullanılan ölçeklerin güvenilirlik analizleri yapılmıştır. Yapılan analiz sonucu web tabanlı öğretim ölçeğinin yüksek derecede güvenilir olduğu ve örgütsel stres ölçeğinin de oldukça güvenilir olduğu sonucuna ulaşılmıştır. Her 
iki ölçekte de uyarlamalar yapıldığı için faktör analizi yapılarak geçerliliklerinin test edilmesi uygun görülmüştür. Bu doğrultuda web tabanlı öğretim ölçeği, web tabanlı öğretimin etkililiği ve web tabanlı öğretime karşı direnme olmak üzere iki ayrı alt boyuta toplanırken; örgütsel stres ölçeği iş yükü, beceri kullanımı, karar serbestliği ve sosyal destek alt boyutlarına ayrılmaktadır. Elde edilen bu bulgular ile her iki ölçeğin de orijinalleri ile benzerlik gösterdiği sonucuna ulaşılması çalışmanın geçerliliği açısından önemlidir.

Katılımcıların demografik özellikleri inceleyebilmek adına frekans analizi yapılmıştır. Elde edilen sonuçlara göre katılımcıların büyük çoğunluğunun erkeklerden oluştuğu görülmektedir. Elde edilen bu sonuç normaldir. Çünkü Harran Üniversitesi verilerine göre akademisyenlerin çoğunluğu erkeklerden oluşmaktadır. Katılımcılar çoğunluklu olarak evli ve yönetsel görevi bulunmayan öğretim elemanlarıdır. Akademik unvan açısında dengeli bir dağılım söz konusudur ve oranlar birbirine yakın olmakla birlikte en çok öğretim görevlilerinden ve daha sonra profesörlerden oluşmaktadır. En az orana sahip unvan grubu ise araştırma görevlileridir. Hizmet süresi açısından da dengeli bir dağılım olmakla birlikte akademisyenlerin çoğunluğunun "24-29 yıl” arasında çalışma süresine sahip olduğu tespit edilmiştir. Bu durum örneklemin tecrübe birikimine sahip akademisyenlerden oluştuğunu ve mevcut uzaktan eğitim sistemini pandemi öncesi yüz yüze eğitim sistemi ile kıyaslama imkânına sahip öğretim elemanları olduklarını göstermektedir. Ders yükü açısından elde edilen sonuçları incelediğimizde akademisyenlerin büyük çoğunluğunun "24 saat ve üstü" ders yüküne sahip olduğunu görmekteyiz. Bu oranı takip eden diğer ders yükü oranları da yine yüksek oranlardır. Bu durumdan hareketle çalışma kapsamındaki akademisyenlerin genel olarak fazla ders yüküne sahip olduğunu söylemek mümkündür. $\mathrm{Bu}$ sonuç akademisyenlerin uzaktan eğitim sürecinde daha fazla yorulmalarına ve yıpranmalarına yol açmış olabilir.

Web tabanlı öğretimin etkililiğinin örgütsel stres üzerindeki etkisini test etmek için basit regresyon analizi yapılmıştır. Analiz sonucunda web tabanlı öğretimin etkililiğinin örgütsel stres üzerinde etkisinin olmadığ 1 tespit edilmiştir. Ayrıca web tabanlı öğretimin etkililiği ile örgütsel stres 
arasındaki ilişkiyi ölçmek için korelasyon analizi gerçekleştirilmiş ve ikisi arasında anlamlı bir ilişki bulunmadığı sonucuna ulaşılmıştır.

Web tabanlı öğretime karşı direnmenin örgütsel stres üzerindeki etkisini test etmek için yapılan basit regresyon analizi sonucunda ise web tabanlı öğretime karşı direnmenin, örgütsel stres üzerinde pozitif ve anlamlı derecede etkili olduğu sonucuna varılmıştır. Ayrıca web tabanlı öğretime karşı direnme ve örgütsel stres değişkenleri arasındaki ilişkiyi ölçmek adına korelasyon analizi gerçekleştirilmiş ve analiz sonucunda bu iki değişken arasında pozitif ve zayıf bir ilişki olduğu sonucuna ulaşılmıştır. Regresyon ve korelasyon analizleri ile elde edilen bulgulardan hareketle web tabanlı öğretimin etkili olduğunu düşünen akademisyenlerin COVID-19 pandemi sürecinde örgütsel stres yaşamadığını ancak web tabanlı öğretime karşı direnen akademisyenlerin örgütsel stres yaşadıklarını söylemek mümkündür.

Her çalışmanın olduğu gibi yapılan bu çalışmanın da bazı kısıtları bulunmaktadır. Araştırmanın yalnızca bir üniversite ile sınırlı tutulması, çalışmanın en önemli kısıtını oluşturmaktadır. Bu nedenle kolayda örnekleme yapıldığı için elde edilen sonuçlar tüm Türkiye'deki akademisyenlere genellenemez. Bu noktada daha sonra yapilacak araştırmaların farklı evren, örneklem ve yöntemlerle tekrarlanması tavsiye edilebilir.

Sonuç olarak uzaktan eğitimi, yüz yüze eğitimi ortadan kaldırmaya yönelik rakip bir sistem olarak görmek yerine yüz yüze eğitim sisteminin yükünü hafifletmeye yönelik bir sistem olarak kabullenmek ilerleyen süreçlerde akademisyenlerin stres düzeyinin azalmasına ve uzaktan eğitime gereken önemin verilmesine yardımcı olabilir. 
EXTENDED ABSTRACT

\title{
The Effect of Online Education on Organizational Stress of Academicians in Covid-19 Process: The Case of Harran University
}

\author{
Abdullah Çelik- Fatmanur Aksöz \\ Harran University
}

The COVID-19 epidemic, which was first detected in Wuhan, China, has taken the whole world under its influence in a short time. The COVID-19 pandemic has had profound effects on health, economic, political, psychological, socio-cultural, social life and educational practices, and the flow of life has changed at a global level. Measures such as flexible working, rotating working, working from home, curfews and quarantine processes have been taken to reduce the impact of the pandemic and slow its spread due to its highly contagious nature. In line with these measures, places where there may be contact between people have been closed, and schools and universities that have serious human interaction are also included in this scope. Face-to-face education was suspended at all education levels, the transition to the distance education system was made, the measurement and evaluation processes of students' success were also carried out on a web-based basis, and central exams were postponed. In this context, the COVID-19 pandemic has also severely affected the higher education system. Thus, a very rapid and compulsory transition from formal education to web-based distance education system has taken place. As a result of this rapid transformation in education systems, it has had an important place in the agenda of countries to offer distance education in an uninterrupted and high quality manner.

The term distance education refers to the education that takes place when the student and the instructor are physically in separate environments. Due importance should be given to the distance education system, which provides education and communication opportunities to students and trainers at a global level. The impact of this need has been felt intensely during the COVID-19 process. Although the distance 
education system was adopted in the teaching of common courses in some universities before, the transition to distance education in all departments and levels was realized for the first time. Students and academics trying to keep up with this new system have faced various problems. The need for a certain period of time for adaptation to the distance education period, the fact that the digital literacy level of the instructors and students is not yet at a sufficient level, there are problems in the processing of the courses that require practice, and the inability of some students to have the necessary devices or to access the internet are among the leading problems. In addition to all these, sudden system changes and uncertainties in the system cause stress for both instructors and students. Today, with the pandemic, this situation has clearly manifested itself. As a matter of fact, it has been clearly understood how important the distance education system is in crisis situations such as epidemics, disasters, forced migration, and war, and that the distance education system must have a strong infrastructure in order to continue education uninterrupted. Because the existence of a distance education system with a strong infrastructure will be the most important factor in preventing the stress to be experienced in such periods. At this point, it was thought that handling the process in terms of academicians would contribute to the distance education system, which has become the main source of learning with COVID-19. Based on this idea, it was deemed necessary to conduct this study.

Stress caused by the individual's self or around and harmony arising from the extreme physical or individual efforts to effect creates psychological pressure can be expressed as a reaction affecting the entire organism. In today's society, work has an important place in people's lives. Because people spend most of their time at work or thinking about work-related issues. However, working life and the organization they work for can be an important stress factor for many people. Organizational stress is one of the main problems in working life. Factors such as complex business models, workload and time pressure are among the components of modern working life. On the other hand, factors that disrupt the routine order and create uncertainty in our lives can cause stress. At this point, it is thought that examining the impact of the sudden change in the education system with the COVID-19 process 
on the stress of academicians will contribute to the ongoing process and the new system. In this direction, the aim of the study is to examine the effect of online education on the organizational stress of academics during the COVID-19 process. The study is a quantitative research and the survey method was used to collect the data to be used in the research. While preparing the questionnaire, studies in the literature were taken into consideration. The questionnaire used in the study consists of three parts. First part; It contains seven questions in order to learn the demographic structures of the academicians participating in the survey. In the second part, "Web-based teaching attitude scale" developed by Erdoğan, Bayram and Deniz (2007) is taken as reference. The aforementioned questionnaire was prepared for students. For this reason, the questions were adapted to measure the attitudes of academics. In the third part, the "Organizational stress scale" developed by Theorell et al. (1988) and adapted into Turkish by the researchers was taken as reference. The scale questions were adapted according to the pandemic conditions. Since adaptations were made in both scales, it was deemed appropriate to test their validity by performing factor analysis. With these findings, it is important for the validity of the study to reach the conclusion that both scales are similar to the originals.

The questionnaire was applied online to 278 academicians working at Harran University in the spring term of the 2020-2021 academic year. The necessary analyzes were made with the SPSS program for the obtained data and the results were interpreted in tables. As a result of the analyzes, it was determined that the majority of the participants had a long period of service and therefore a large amount of experience, the majority of them were lecturers and professors, and the course load was high. At this point, it has been concluded that the researched academicians have the experience to compare face-to-face education and distance education. Moreover, as a result of the analyzes made, it is possible to say that academics who think web-based teaching is effective did not experience organizational stress during the COVID-19 pandemic, but academics who resist web-based teaching experience organizational stress. 


\section{Kaynakça/References}

Akdemir, Ö. (2011). Yükseköğretimimizde uzaktan eğitim. Yükseköğretim ve Bilim Dergisi, 1(2), 69-71.

Altunışık, R., Coşkun, R., Bayraktaroğlu, S. ve Yıldırım, E. (2005). Sosyal bilimlerde araştırma yöntemleri SPSS uygulamal. Adapazarı: Sakarya Kitabevi.

Arslan, B. (2020). Materyalizm ve marka rezonansının tüketicilerin tekrar satın alma davranışına etkisi. OPUS-Uluslararası Toplum Araştırmaları Dergisi, 16(Özel Sayı), 3387-3410.

Atasoy, R., Özden, C. ve Kara, D. N. (2020). COVID-19 pandemi sürecinde yapılan E-ders uygulamalarının etkililiğinin öğrencilerin perspektifinden değerlendirilmesi. Turkish Studies, 15(6), 95-122.

Aydın, B. ve Doğan, M. (2020). Yeni koronavirüs (COVID-19) pandemisinin turistik tüketici davranışları ve Türkiye turizmi üzerindeki etkilerinin değerlendirilmesi. Pazarlama Teorisi ve Uygulamaları Dergisi, 6(1), 93115.

Aydın, İ. (2008). İş yaşamında stres. Ankara: Pegem Yayınevi.

Bozkurt, A. (2017). Türkiye'de uzaktan eğitimin dünü, bugünü ve yarını. AUAd, 3(2), 85-124.

Bozkurt, A. (2020). Koronavirüs (COVID-19) pandemi süreci ve pandemi sonrası dünyada eğitime yönelik değerlendirmeler: Yeni normal ve yeni eğitim paradigması. AUAd, 6(3), 112-142.

Budak, F. ve Korkmaz, Ş. (2020). COVID-19 pandemi sürecine yönelik genel bir değerlendirme: Türkiye örneği. Sosyal Araştırmalar ve Yönetim Dergisi (SAYOD), (1), 62-79.

Can, E. (2020). Coronavirüs (COVID-19) pandemisi ve pedagojik yansımaları: Türkiye' de açık ve uzaktan eğitim uygulamaları. AUAd, 6(2), 11-53.

Demiral, Y., Ünal, B., Kılıı̧, B., Soysal, A., Bilgin, A. C., Uçku, R. ve Theorell, T. (2007). İş stresi ölçeğinin İzmir Konak Belediyesi'nde çalışan erkek işçilerde geçerlik ve güvenilirliğinin incelenmesi. Toplum Hekimliğ $i$ Bülteni, 26(1), 11-18.

Durmuş, B., Yurtkoru E.S. ve Çinko, M. (2016). Sosyal Bilimlerde SPSS'le veri analizi. İstanbul: Beta Yayınları.

Düzakın, D. ve Yalçınkaya, S. (2008). Web tabanlı uzaktan eğitim sistemi ve Çukurova Üniversitesi öğretim elemanlarının yatkınlıkları. Çukurova Üniversitesi Sosyal Bilimler Enstitüsü Dergisi, 17(1), 225-244. 
Erdoğan, Y., Bayram, S. ve Deniz, L. (2007). Web tabanlı öğretim tutum ölçeği: Açıklayıcı ve doğrulayıcı faktör analizi çalışması. Uluslararası İnsan Bilimleri Dergisi, 4(2), 1-14.

Gümüştekin Eren, G. ve Öztemiz, A. B. (2004). Örgütsel stres yönetimi ve uçucu personel üzerinde bir uygulama. Erciyes Üniversitesi İktisadi ve İdari Bilimler Fakültesi Dergisi, 23, 61-85.

Güngör, B. (2020). Türkiye'de COVID-19 pandemisi süresince alınan önlemlerin kriz yönetimi perspektifinden değerlendirilmesi. Uluslararası Sosyal Bilimler Akademi Dergisi, 2(4), 818-851.

Güreşçi, M. (2020). COVID-19 salgınında Türkiye'de kriz yönetimi iletişimi: T.C. Sağlık Bakanlığı. Avrasya Sosyal ve Ekonomi Araştırmaları Dergisi (ASEAD), 7(5), 53-65.

İşman, A. (2011). Uzaktan Eğitim. Ankara: Pegem Akademi.

Keskin, M. ve Özer Kaya, D. (2020). COVID-19 sürecinde öğrencilerin web tabanlı uzaktan eğitime yönelik geri bildirimlerinin değerlendirilmesi. İzmir Kâtip Çelebi Üniversitesi Sağlık Bilimleri Fakültesi Dergisi, 5(2), 5967.

Kurnaz, E. ve Serçemeli, M. (2020). COVID-19 pandemi döneminde akademisyenlerin uzaktan eğitim ve uzaktan muhasebe eğitimine yönelik bakış açıları üzerine bir araştırma. Uluslararası Sosyal Bilimler Akademi Dergisi (USBAD), 2(3), 263-288.

Odabaş, H. (2003). İnternet tabanlı uzaktan eğitim ve bilgi ve belge yönetimi bölümleri. Türk Kütüphaneciliği, 17(1), 22-36.

Öztürk, B. (2018). Örgütsel stresle başa çıkma, örgütsel adalet algısl, iş tatmini ve duyguların üretkenlik karşıtı iş dauranışlarındaki rolü. (Yayınlanmamış yüksek lisans tezi). Tobb Ekonomi ve Teknoloji Üniversitesi, Sosyal Bilimler Enstitüsü, İşletme Ana Bilim Dalı, Ankara.

Soysal, A. (2009). Farklı sektörlerde çalışan iş görenlerde örgütsel stres kaynakları: Kahramanmaraş ve Gaziantep'te bir araştırma. Süleyman Demirel Üniversitesi İktisadi ve İdari Bilimler Fakültesi Dergisi, 14(2), 333359.

Şahin Erbaş, E. (2019). Örgütsel stres, çatı̧̧a ve işten ayrılma niyeti arasındaki ilişki üzerine bir inceleme. (Yayınlanmamış yüksek lisans tezi). Marmara Üniversitesi, Sosyal Bilimler Enstitüsü, Çalışma Ekonomisi ve Endüstri İlişkileri Ana Bilim Dalı, İstanbul. 
Theorell T, Perski A, Akerstedt T, Sigala F, Ahlberg-Hulten G, Svensson J et al. (1988) Changes in job strain in relation to changes in physiological state. Scand J Work Environ Health, 14(3), 189-196.

Yamamoto Telli, G. ve Altun, D. (2020). Coronavirüs ve çevrimiçi(online) eğitimin önlenemeyen yükselişi. Üniversite Araştırmaları Dergisi, 3(1), 25-34.

Yamuç, V., Türker, D. (2015). Örgütsel stres kaynaklarının analizi: Bir üretim işletmesinde kadın ve erkek çalışanlar üzerine inceleme. Yönetim Bilimleri Dergisi, 13(25), 389-423.

Yaşlıŏlu, M. (2017). Sosyal Bilimlerde faktör analizi ve geçerlilik: Keşfedici ve Doğrulayıcı Faktör Analizlerinin Kullanılması. İstanbul Üniversitesi İşletme Fakültesi Dergisi, 46(0), 74-85.

Yıldız, S. (2017). Sosyal bilimlerde örnekleme sorunu: Nicel ve nitel paradigmalardan örnekleme kuramına bütüncül bir bakış. Kesit Akademi Dergisi, 3(11), 421-442.

Yılmaz, A. ve Ekici, S. (2006). Örgütsel yaşamda kamu çalışanlarının örgütsel stres kaynakları üzerine bir araştırma. S.D.Ü. İ.I.B.F. Dergisi, 11(1), 3158.

YÖK.

(2020f).

Basin

açıklaması.

https://www.yok.gov.tr/Sayfalar/Haberler/2020/YKS\%20Ertelenmesi\%20Ba sin\%20Açı klaması.aspx, web adresinden 03 Aralık 2020 tarihinde edinilmiştir.

YÖK. (2020g). YÖK'ten üniversite öğrencileri için kayıt dondurma ve erteleme hakkı. https://www.yok.gov.tr/Sayfalar/Haberler/2020/erteleme-ve-kayitdondurmahakki.aspx, web adresinden 04 Aralık 2020 tarihinde edinilmiştir.

\section{Kaynakça Bilgisi / Citation Information}

Çelik, A. ve Aksöz, F. (2021). Covid-19 sürecinde online eğitimin akademisyenlerin örgütsel stresine etkisi: Harran Üniversitesi örneği. OPUS- Uluslararası Toplum Araştırmaları Dergisi, 18(43), 6564-6594. DOI: 10.26466/opus.939850. 